\title{
Validated HPTLC Method for Simultaneous Estimation of Isotretinoin and Erythromycin in Bulk Drug and Topical Gel Form
}

\author{
Atul S. Rathore, Lohidasan Sathiyanarayanan, Kakasaheb R. Mahadik ${ }^{*}$ \\ Department of Pharmaceutical Chemistry, Poona College of Pharmacy, \\ Bharati Vidyapeeth University, Pune, India \\ E-mail: krmahadik@rediffmail.com \\ Received June 16, 2010; revised August 2, 2010; accepted October 26, 2010
}

\begin{abstract}
A simple, precise and accurate high performance thin layer chromatographic method has been developed for the simultaneous estimation of Isotretinoin and Erythromycin in pharmaceutical gel. The separation was carried out on Merck TLC aluminum sheets of silica gel $60 \mathrm{~F}_{254},(20 \times 10 \mathrm{~cm})$ with $250 \mu \mathrm{m}$ thickness using toluene: DMSO: methanol (6.5:0.2:2.5, v/v/v) as a mobile phase. HPTLC separation of the two drugs followed by densitometric measurement of their spots at $340 \mathrm{~nm}$ for Isotretinoin before derivatization and 410 $\mathrm{nm}$ for Erythromycin after derivatization with $10 \% \mathrm{H}_{2} \mathrm{SO}_{4}$ and heating at $100^{\circ} \mathrm{C}$ for $15 \mathrm{~min}$. The drugs were satisfactorily resolved with $\mathrm{R}_{\mathrm{F}}$ values of $0.38 \pm 0.02$ and $0.55 \pm 0.02$ for Isotretinoin and Erythromycin, respectively. The accuracy and reliability of the method was assessed by evaluation of linearity (30-150 ng spot $^{-1}$ for Isotretinoin and 1200-6000 ng spot ${ }^{-1}$ for Erythromycin), precision (intra-day RSD 0.62-0.79\% and inter-day RSD $0.43-0.71 \%$ for Isotretinoin and intra-day RSD $0.47-1.71 \%$ and inter-day RSD $0.42-1.49 \%$ for Erythromycin), accuracy ( $98.91 \pm 0.92 \%$ for Isotretinoin and $99.27 \pm 0.72 \%$ for Erythromycin), and specificity, in accordance with ICH guidelines.
\end{abstract}

Keywords: Isotretinoin, Erythromycin, HPTLC, Validation

\section{Introduction}

Isotretinoin (Figure 1(a)) is chemically (13cis)-retinoic acid. Isotretinoin is a member of the large group of $\mathrm{Vi}$ tamin A related compounds. It alters DNA transcription and decreases the size and sebum output of the sebaceous glands. It also stabilizes keratinization, Due to its effect on regulating cell differentiation it has been used for the treatment of cystic and nodular acne and also as an inhibitor of neoplasic cells proliferation [1-7]. Erythromycin (Figure 1(b)) is chemically (3R, 4S, 5S, 6R, 7R, 9R, 11R, 12R, 13S, 14R)-6-\{[(2S, 3R, 4S, 6R)-4-(di- methylamino)-3-hydroxy-6-methyloxan-2-yl]oxy $\}$-14ethyl-7, 12, 13-trihydroxy-4-\{[(2R, 4R, 5S, 6S)-5-hydroxy-4-methoxy-4,6-dimethyloxan-2-yl]oxy\}-3, 5, 7, 9, 11, 13-hexamethyl-1-oxacyclotetradecane-2,10-dione. It is an antibiotic that possess bactericidal activity, particularly at higher concentrations. It acts by binding to the 50s subunit of the bacterial 70s rRNA complex, protein synthesis and subsequently structure/function processes critical for life or replication are inhibited [8,9]. Literature review reveals that several analytical methods have been reported for Isotretinoin [10-12] and Erythromycin [13-18] as individual determination or in biological fluids or in combination with other drugs in pharmaceutical dosage forms. A comprehensive literature survey revealed that no method has been reported for simultaneous estimation of Isotretinoin and Erythromycin by HPTLC in pharmaceutical dosage forms. So, the present study is designed for the development and validation of simple HPTLC method for the simultaneous estimation of Isotretinoin and Erythromycin in their combined topical gel formulation. The proposed method is validated as per ICH guideline [19].

\section{Experimental}

\subsection{Materials}

Working standards of pharmaceutical grade Isotretinoin 
<smiles>CC1=C(/C=C/C(C)=C/C=C/C(C)=C\C=O)C(C)(C)CCC1</smiles>

(a)

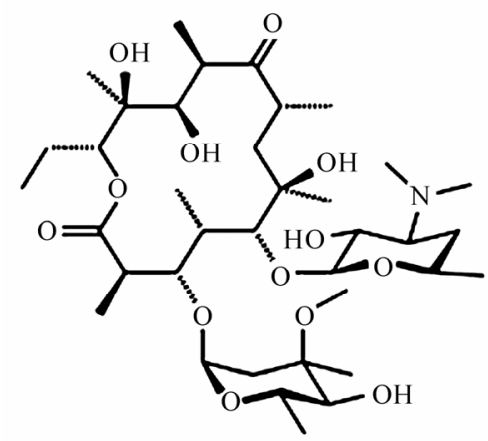

(b)

Figure 1. (a) Structure of Isotretinoin; (b) Structure of Erythromycin.

and Erythromycin were obtained as a gift sample from Ranbaxy laboratory ltd. Dewas, India. Formulation in the form of gel (Isotrexin) was procured as a gift sample from Stiefel Laboratories (Ireland) Ltd., Silgo, Ireland containing $0.05 \%$ Isotretinoin and $2 \%$ Erythromycin $(w / w)$. All chemicals and reagents of analytical grade were purchased from Merck Chemicals, Mumbai, India. High purity deionized water was obtained from Millipore, Milli-Q (Bedford, MA, USA) water purification system.

\subsection{Preparation of Standard Stock and Working Solutions}

Stock standard solution containing Isotretinoin $(150 \mu \mathrm{g}$ $\left.\mathrm{mL}^{-1}\right)$ and Erythromycin (6000 $\mu \mathrm{g} \mathrm{mL}^{-1}$ ) was prepared by dissolving $7.5 \mathrm{mg}$ Isotretinoin and $300 \mathrm{mg}$ Erythromycin in methanol in a $50 \mathrm{~mL}$ volumetric flask. Working standard solution of Isotretinoin and Erythromycin was prepared at concentration of $15 \mathrm{ng} \mu \mathrm{L}^{-1}$ and $600 \mathrm{ng} \mu \mathrm{L}^{-1}$ respectively, by diluting the stock standard solution in methanol. The stock solution was stored at $2-8^{\circ} \mathrm{C}$ protected from light.

\subsection{Instrumentation}

The samples were spotted in the form of bands $6 \mathrm{~mm}$ width with a Camag 100 microlitre sample syringe (Hamilton, Bonaduz, Switzerland) on silica gel precoated aluminum plate $60 \mathrm{~F}_{254},[(20 \times 10 \mathrm{~cm})$ with $250 \mu \mathrm{m}$ thickness; E. Merck, Darmstadt, Germany, supplied by Anchrom Technologists, Mumbai] using a Camag Linomat IV applicator (Switzerland). The plates were pre- washed with methanol and activated at $110^{\circ} \mathrm{C}$ for 5 min prior to chromatography. A constant application rate of $0.1 \mu \mathrm{Ls}^{-1}$ was used and the space between two bands was $6 \mathrm{~mm}$. The slit dimension was kept at $5 \mathrm{~mm} \times 0.45 \mathrm{~mm}$ and the scanning speed was $10 \mathrm{~mm} \mathrm{~s}^{-1}$. The mobile phase was consisted of toluene: DMSO: methanol (6.5:0.2:2.5, $\mathrm{v} / \mathrm{v} / \mathrm{v}$ ) and $18.4 \mathrm{~mL}$ were used per chromatography run. Linear ascending development was carried out in $20 \mathrm{~cm} \times$ $10 \mathrm{~cm}$ twin trough glass chamber (Camag, Muttenz, Switzerland) saturated with the mobile phase. The optimized chamber saturation time for mobile phase was 30 $\mathrm{min}$ at room temperature $\left(25 \pm 2^{\circ} \mathrm{C}\right)$. The length of chromatogram run was $8 \mathrm{~cm}$. Densitometric scanning was performed using a Camag TLC scanner III in the reflectance-absorbance mode and operated by CATS software (V 3.15, Camag). The sources of radiation used were deuterium and tungsten lamp with a spectral range from 190 to $800 \mathrm{~nm}$. Concentrations of the compound chromatographed were determined from the intensity of the diffused light. Evaluation was by peak areas with linear regression.

\subsection{Selection of Analytical Wavelength}

A UV spectrum for the solution $\left(10 \mu \mathrm{g} \mathrm{mL} \mathrm{m}^{-1}\right)$ of Isotretinoin was recorded in a $10 \mathrm{~mm}$ cell over the range 200-400 nm using methanol in the reference cell. Isotretinoin showed maximum absorbance at $340 \mathrm{~nm}$ (Figure 2) while Erythromycin was detected at $410 \mathrm{~nm}$ after derivatization with $10 \% \mathrm{H}_{2} \mathrm{SO}_{4}$ and heating at $100{ }^{\circ} \mathrm{C}$ for $15 \min [13]$.

\subsection{Optimization of HPTLC Method}

The HPTLC procedure was optimized with a view to develop a simultaneous assay method for Isotretinoin and Erythromycin. The stock standard solution containing

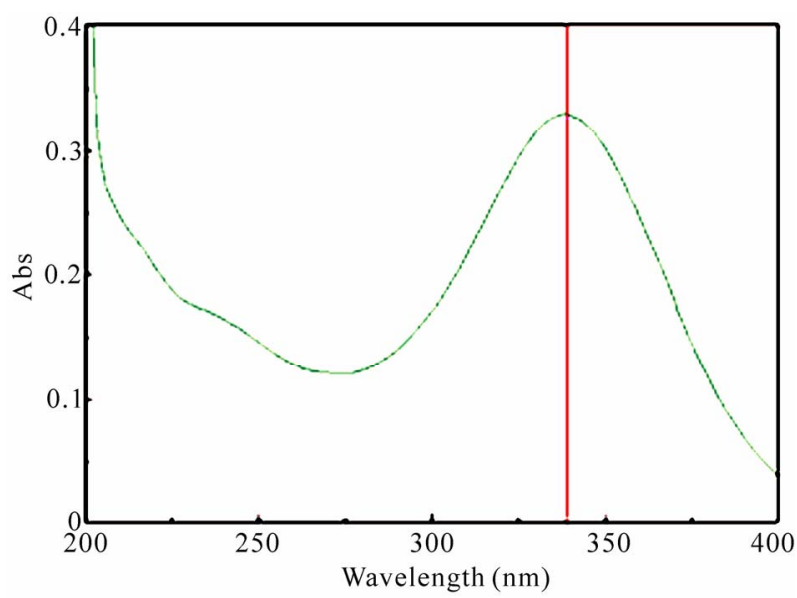

Figure 2. UV spectrum of Isotretinoin. 
$150 \mu \mathrm{g} \mathrm{mL} \mathrm{m}^{-1}$ of Isotretinoin and $6000 \mu \mathrm{g} \mathrm{mL}^{-1}$ of Erythromycin were spotted onto Merck HPTLC silica gel precoated aluminum plate $60 \mathrm{~F}_{254},(20 \times 10 \mathrm{~cm})$ with 250 $\mu \mathrm{m}$ thickness and run in different solvent systems. Initially, toluene, ethyl acetate and methanol were tried in different ratio. (Toluene, acetone and methanol) and (hexane, acetone and methanol) were tried in various ratio. Finally, toluene, DMSO and methanol were tried. It was found that the DMSO is responsible for the elution of erythromycin. The optimum mobile phase was found to be consisted of toluene: DMSO: methanol (6.5:0.2:2.5, $\mathrm{v} / \mathrm{v} / \mathrm{v})$. The drugs were satisfactorily resolved with RF values at $0.38 \pm 0.02$ and $0.55 \pm 0.02$ for Isotretinoin and Erythromycin, respectively. In order to reduce the neckless effect the TLC chamber was saturated for $30 \mathrm{~min}$ using saturation pads. The mobile phase was run up to a distance of $8 \mathrm{~cm}$; which takes approximately $45 \mathrm{~min}$. for complete development of the TLC plate.

\subsection{Validation of HPTLC Method}

The optimized HPTLC method was validated with respect to the following Parameters. The validation was performed as per the ICH guideline [19].

\subsubsection{Linearity}

Stock standard solution containing $150 \mu \mathrm{g} \mathrm{mL} \mathrm{m}^{-1}$ of Isotretinoin and $6000 \mu \mathrm{g} \mathrm{mL}^{-1}$ of erythromycin was further diluted with methanol to obtain a working standard solution at concentration of $15 \mathrm{ng} \mu \mathrm{L}^{-1}$ and $600 \mathrm{ng} \mu \mathrm{L}^{-1}$ respectively. From the working standard solution 2, 4, 6, 8, $10 \mu \mathrm{L}$ volumes were spotted on HPTLC plate to obtain a final concentration range of 30-150 ng spot ${ }^{-1}$ for Isotretinoin and 1200-6000 ng spot ${ }^{-1}$ for Erythromycin. Each concentration was applied six times on the TLC plate. The plate was then developed using the previously described mobile phase. Curves were obtained by plotting the peak area against concentration of the drug. Linear calibration curves were generated using least-squares linear-regression analysis.

\subsubsection{Precision}

The precision of the method was verified by repeatability (intraday) and intermediate precision studies. Repeatability studies were performed by analysis of three different concentrations of 30, 90, $150 \mathrm{ng} \mathrm{spot}^{-1}$ and 1200, 3600, $6000 \mathrm{ng} \mathrm{spot}^{-1}$ for Isotretinoin and Erythromycin, respectively. Method repeatability was achieved from RSD \% values obtained by repeating the assay six times on the same day for intra-day precision. The intermediate (interday) precision of the method was checked by performing same procedure on different days under the same experimental conditions.

\subsubsection{Robustness}

The robustness was studied by evaluating the effect of small but deliberate variations in the chromatographic conditions. Following the introduction of small changes in the mobile phase composition $( \pm 0.1 \mathrm{~mL}$ for each component), the effects on the results was examined. Mobile phases having different compositions, e.g. toluene: DMSO: methanol (6.5:0.2:2.5, v/v/v), (6.5:0.2:2.4, $\mathrm{v} / \mathrm{v} / \mathrm{v}),(6.5: 0.2: 2.6, \mathrm{v} / \mathrm{v} / \mathrm{v})$, were tried and chromatograms were run. The amount of mobile phase was varied over the range of $\pm 5 \%$. The time from spotting to chromatography and from chromatography to scanning was varied from $\pm 10 \mathrm{~min}$. The robustness of the method was determined at three different concentration levels of 30, 90, $150 \mathrm{ng} \mathrm{spot}^{-1}$ for Isotretinoin and 1200, 3600, 6000 ng spot $^{-1}$ for Erythromycin.

\subsubsection{Specificity}

The ability of an analytical method to unequivocally assess the analyte in the presence of other components can be demonstrated by evaluating specificity. The specificity of the HPTLC method was determined by analyzing standard drug and test samples. The spot for Isotretinoin and Erythromycin in the samples was confirmed by comparing the RF and spectrum of the spot to that of a standard. The peak purity of Isotretinoin and Erythromycin was determined by comparing the spectrum at three different regions of the spot i.e. peak start (S), peak apex (M) and peak end (E).

\subsubsection{Accuracy}

Accuracy of the HPTLC method was carried out by applying the method to drug sample [Isotretinoin $0.05 \%$ and Erythromycin 2\% (w/w) combination in gel form of alcoholic base of $30 \mathrm{~g}$ tube] to which known amount of Isotretinoin and erythromycin standard powder corresponding to 50, 100 and $150 \%$ of label claim was added (standard addition method). The absolute recovery was calculated by comparing the peak areas obtained from standard solution of Isotretinoin and Erythromycin with the peak areas of samples of different concentration.

\subsubsection{Analysis of a Marketed Formulation (Assay)}

Isotrexin Gel $30 \mathrm{~g}$ tube (labeled to contain Isotretinoin $0.05 \%$ and Erythromycin $2 \%$ (w/w) in gel form of alcoholic base of $30 \mathrm{~g}$ tube, Stiefel India Ltd.) means 15 $\mathrm{mg} / 30 \mathrm{~g}$ of Isotretinoin and $600 \mathrm{mg} / 30 \mathrm{~g}$ of Erythromycin. An accurate weight of the 1 gram of gel equivalent to $0.5 \mathrm{mg}$ of Isotretinoin and $20 \mathrm{mg}$ of Erythromycin was transferred into a $10 \mathrm{~mL}$ volumetric flask containing 8 $\mathrm{mL}$ methanol and sonicated for $30 \mathrm{~min}$. The contents were restored to room temperature and diluted to volume with methanol to furnish stock test solution. The stock 
solution was filtered through a $0.45 \mu \mathrm{m}$ Nylon syringe filter. From the stock test solution (containing $50 \mathrm{ng} \mu \mathrm{L}^{-1}$ of Isotretinoin and $2000 \mathrm{ng} \mu \mathrm{L}^{-1}$ of Erythromycin), $2 \mu \mathrm{L}$ volume was spotted for six times to achieve a final concentration of $100 \mathrm{ng} \mathrm{spot}^{-1}$ and $4000 \mathrm{ng} \mathrm{spot}^{-1}$ for Isotretinoin and Erythromycin, respectively.

\section{Results and Discussion}

In this work HPTLC method for the analysis of Isotretinoin and Erythromycin in topical gel form was developed and validated as per ICH, Q2 (R1), guideline.

\subsection{Optimization of Procedures}

The experimental conditions for HPTLC such as wavelength of detection and mobile phase composition were optimized to provide accurate, precise and reproducible results for the simultaneous determination of Isotretinoin and Erythromycin. A scanning wavelength of $340 \mathrm{~nm}$ for Isotretinoin was obtained from UV spectrum and $410 \mathrm{~nm}$ for Erythromycin after derivatization with $10 \% \mathrm{H}_{2} \mathrm{SO}_{4}$ and heating at $100^{\circ} \mathrm{C}$ for $15 \mathrm{~min}$ [13]. A good resolution was obtained by using an optimum mobile phase consisted of toluene: DMSO: methanol (6.5:0.2:2.5, v/v/v). Isotretinoin and Erythromycin were satisfactorily resolved with RF values at $0.38 \pm 0.02$ and $0.55 \pm 0.02$, respectively (Figure 3 ).

\subsection{Method Validation}

\subsubsection{Linearity}

Linear relationships were observed by plotting drug concentrations against peak areas for each compound. Isotretinoin and Erythromycin showed linear response in the concentration range of 30-150 $\mathrm{ng} \mathrm{spot}^{-1}$ and 1200$6000 \mathrm{ng} \mathrm{spot}{ }^{-1}$, respectively. The corresponding linear regression equation was $\mathrm{y}=3.774 \mathrm{x}+468.7$ and $\mathrm{y}=2.22 \mathrm{x}$ - 974.1 with square of correlation coefficient $\left(R^{2}\right)$ of $0.997 \pm 0.066$ and $0.996 \pm 0.071$ for Isotretinoin and Erythromycin, respectively (Table 1).

\subsubsection{Precision}

The results of the repeatability and intermediate precision experiments are shown in Table 2. The developed methods were found to be precise as the RSD values for repeatability and intermediate precision studies were < $2 \%$, respectively as recommended by ICH guidelines.

\subsubsection{Robustness}

The standard deviation of the peak areas was calculated for each parameter and the RSD was found to be less than $2 \%$ for HPTLC. The low values of the RSD\%, as shown in Table 3. indicated the robustness of the proposed method.

\subsubsection{Specificity}

The peak purity of Isotretinoin and Erythromycin was assessed by comparing their respective spectra at the peak start, apex and peak end positions of the spot i.e., $r$ $(\mathrm{S}, \mathrm{M})=0.9979$ and $\mathrm{r}(\mathrm{M}, \mathrm{E})=0.9986$. A good correlation $(\mathrm{r}=0.9981)$ was also obtained between the standard and sample spectra of Isotretinoin and Erythromycin.

Table 1. Linear regression data for the calibration curves.

\begin{tabular}{ccc}
\hline Parameters & Isotretinoin & Erythromycin \\
\hline Linearity range & $30-150 \mathrm{ng} \mathrm{spot}^{-1}$ & $1200-6000 \mathrm{ng} \mathrm{spot}^{-1}$ \\
$\mathrm{r}^{2} \pm$ S.D. & $0.997 \pm 0.066$ & $0.996 \pm 0.071$ \\
Slope \pm S.D. & $3.774 \pm 0.042$ & $2.22 \pm 0.099$ \\
Intercept \pm S.D & $468.7 \pm 0.528$ & $974.1 \pm 0.984$ \\
\hline
\end{tabular}

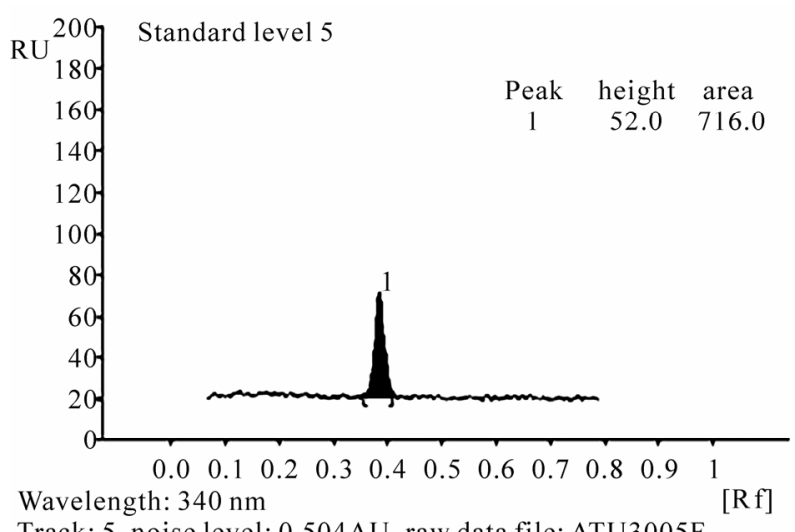

Track: 5, noise level: 0.504AU, raw data file: ATU3005F

(a)

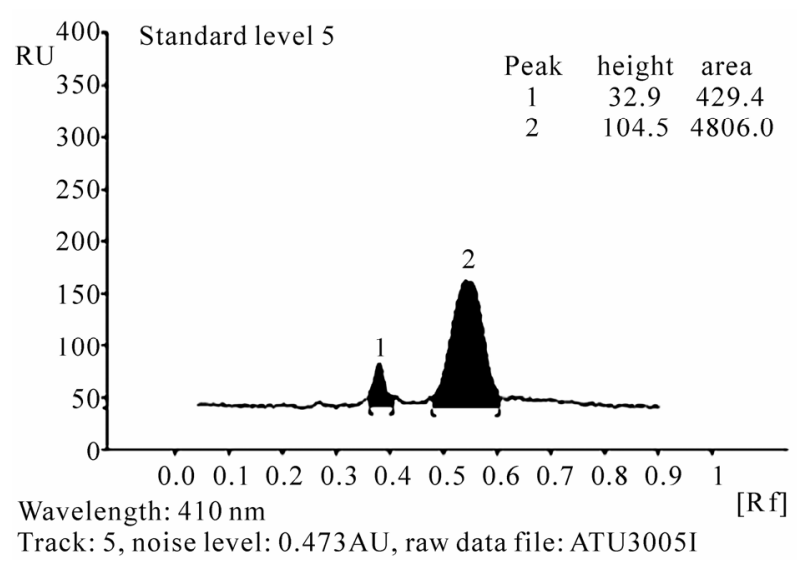

(b)

Figure 3. (a) Densitogram of Isotretinoin $60 \mathrm{ng} \mathrm{spot}^{-1}$ before derivatization at $340 \mathrm{~nm}$; (b) Densitogram of Erythromycin $2400 \mathrm{ng}$ spot $^{-1}$ after derivatization at $410 \mathrm{~nm}$. 
Table 2. Precision studies of Isotretinoin and Erythromycin.

\begin{tabular}{|c|c|c|c|c|c|}
\hline \multirow{2}{*}{ Drugs } & \multirow{2}{*}{ Conc. (ng spot ${ }^{-1}$ ) } & \multicolumn{2}{|c|}{ Repeatability $(\mathrm{n}=6)$} & \multicolumn{2}{|c|}{ Intermediate precision $(n=6)$} \\
\hline & & Found conc. \pm SD & RSD (\%) & Found conc. \pm SD & RSD (\%) \\
\hline \multirow{3}{*}{ Isotretinoin } & 30 & $29.53 \pm 0.18$ & 0.62 & $29.97 \pm 0.13$ & 0.43 \\
\hline & 90 & $90.08 \pm 0.09$ & 0.10 & $90.86 \pm 0.64$ & 0.71 \\
\hline & 150 & $152.88 \pm 1.21$ & 0.79 & $152.14 \pm 0.69$ & 0.45 \\
\hline \multirow{3}{*}{ Erythromycin } & 1200 & $1067.00 \pm 15.47$ & 1.45 & $1038.89 \pm 4.40$ & 0.42 \\
\hline & 3600 & $3690.23 \pm 17.44$ & 0.47 & $3637.13 \pm 54.99$ & 1.49 \\
\hline & 6000 & $5993.19 \pm 101.37$ & 1.71 & $5934.68 \pm 59.99$ & 1.02 \\
\hline
\end{tabular}

Table 3. Robustness testing for HPTLC method.

\begin{tabular}{|c|c|c|c|c|}
\hline \multirow{2}{*}{ Parameter } & \multicolumn{2}{|c|}{ SD of peak area } & \multicolumn{2}{|c|}{$\%$ RSD } \\
\hline & Isotretinoin & Erythromycin & Isotretinoin & Erythromycin \\
\hline Mobile phase composition $( \pm 0.1 \mathrm{ml})$ & 1.54 & 1.53 & 1.24 & 1.09 \\
\hline Amount of mobile phase $( \pm 5 \%)$ & 1.82 & 0.65 & 1.34 & 1.27 \\
\hline Time from spotting to chromatography ( $\pm 10 \mathrm{~min}$ ) & 0.70 & 0.94 & 0.40 & 0.89 \\
\hline Time from chromatography to scanning ( $\pm 10 \mathrm{~min}$ ) & 0.72 & 0.59 & 0.48 & 0.40 \\
\hline
\end{tabular}

Table 4. Accuracy of the proposed method.

\begin{tabular}{|c|c|c|c|c|c|c|c|}
\hline \multirow{2}{*}{ Drugs } & \multirow{2}{*}{$\begin{array}{l}\text { Label claim } \\
\mathrm{mg} \mathrm{g}^{-1} \text { of gel }\end{array}$} & \multirow{2}{*}{$\begin{array}{c}\text { Amount added in } \\
\text { mg (\%) }\end{array}$} & \multirow{2}{*}{$\begin{array}{l}\text { Total amount } \\
\text { (mg) }\end{array}$} & \multirow{2}{*}{$\begin{array}{l}\text { Actual conc. } \\
\text { taken (ng spot }{ }^{-1} \text { ) }\end{array}$} & \multicolumn{3}{|c|}{ For HPTLC $(n=6)$} \\
\hline & & & & & calculated conc. \pm SD & RSD (\%) & Recovery (\%) \\
\hline \multirow{3}{*}{ Isotretinoin } & \multirow{3}{*}{0.5} & $0.25(50 \%)$ & 0.75 & 75 & $73.69 \pm 0.38$ & 0.52 & 98.26 \\
\hline & & $0.5(100 \%)$ & 1.00 & 100 & $98.75 \pm 1.29$ & 1.31 & 98.75 \\
\hline & & $0.75(150 \%)$ & 1.25 & 125 & $124.65 \pm 1.14$ & 0.92 & 99.72 \\
\hline \multirow{3}{*}{ Erythromycin } & \multirow{3}{*}{20} & $10(50 \%)$ & 30 & 3000 & $2942.10 \pm 17.36$ & 0.59 & 98.07 \\
\hline & & $20(100 \%)$ & 40 & 4000 & $4062.00 \pm 17.22$ & 0.42 & 101.55 \\
\hline & & $30(150 \%)$ & 50 & 5000 & $4909.50 \pm 56.37$ & 1.15 & 98.19 \\
\hline
\end{tabular}

\subsubsection{Accuracy}

As shown from the data in Table 4, satisfactory recoveries \% with small relative standard deviations, RSD (\%) were obtained at various added concentrations for both the drugs. The results indicate the methods are highly accurate for simultaneous determination of the two drugs.

\subsubsection{Analysis of a Marketed Formulation (Assay)}

Using the proposed chromatographic method, assay of
Isotretinoin and Erythromycin in their formulation in gel form was carried out. Satisfactory results were obtained for both drugs in a good agreement with the label claims. The recovery $\% \pm$ RSD $\%$ of six replicate determinations were $98.78 \pm 0.99$ (Isotretinoin), $101.19 \pm 1.05$ (Erythromycin) by HPTLC (Table 5).

\section{Conclusions}

The developed TLC technique is precise, specific and 
Table 5. Analysis of marketed formulation (assay) of isotretinoin and erythromycin.

\begin{tabular}{cccc}
\hline & & \multicolumn{2}{c}{ For HPTLC $(\mathrm{n}=6)$} \\
\cline { 3 - 4 } Drugs & $\begin{array}{c}\text { Label claim \% } \\
\text { in 30 g gel }\end{array}$ & $\begin{array}{c}\text { Drug content } \\
(\%) \pm \text { SD }\end{array}$ & RSD (\%) \\
\hline Isotretinoin & $0.05 \%$ & $98.78 \pm 0.98$ & 0.99 \\
Erythromycin & $2 \%$ & $101.19 \pm 1.06$ & 1.05 \\
\hline
\end{tabular}

accurate. Statistical analysis proves that the method is suitable for analsizing of Isotretinoin and Erythromycin as bulk drug and in pharmaceutical gel formulation. The proposed TLC method is less expensive, simpler, rapid, and more flexible than LC.

\section{Acknowledgements}

The authors would like to thank, Ranbaxy laboratory ltd. Dewas, India for the gift samples and Mr. Vijayanand Chakrapani QA-Manager Stiefel India Pvt. Ltd. for arranging the gift sample of formulation (Isotrexin gel) and Poona College of Pharmacy, Bharati Vidyapeeth University for providing facilities and encouragement for carrying out this study.

\section{References}

[1] M. B. Sporn, N. M. Dunlop, D. L. Newton and J. M. Smith, "Prevention of Chemical Carcinogenesis by Vitamin A and Its Synthetic Analogs (Retinoids)," Federation Proceedings, Vol. 35, No. 6, 1976, pp. 1332-1338.

[2] L. R. Harisiadis, R. C. Miller, E. J. Hall and C. Borek, “A Vitamin A Analogue Inhibits Radiation-Induced Oncogenic Transformation,” Nature, Vol. 274, No. 5670, August 1978, pp. 486-487.

[3] R. Lotan, "Effects of Vitamin A and Its Analogs (Retinoids) on Normal and Neoplastic Cells,” Biochimica et Biophysica Acta, Vol. 605, No. 1, March 1980, pp. 33-91.

[4] M. B. Sporn and A. B. Roberts, "What is a Retinoid?" Ciba Foundation Symposium, Vol. 113, 1985, pp. 1-5.

[5] S. Nagpal, J. Athanikar and R. A. S. Chandraratna, "Separation of Transactivation and AP1 Antagonism Functions of Retinoic Acid Receptor," Journal of Biological Chemistry, Vol. 270, No. 2, January 1995, pp. 923-927.

[6] R. A. S. Chandraratna, "Tazarotene-First of a New Generation of Receptor-Selective Retinoids," British Journal of Dermatology, Vol. 135, No. 49, October 1996, pp. $18-25$.

[7] B. Amichai, A. Shemer and M. Grunwald, "Low-Dose Isotretinoin in the Treatment of Acne Vulgaris," Journal of the American Academy of Dermatology, Vol. 54, No. 4, April 2006, pp. 644-646.

[8] C. Mims, H. M. Dockrell, R. V. Goering, I. Roitt, D.
Wakelin and M. Zuckerman, "Attacking the Enemy: Antimicrobial Agents and Chemotherapy: Macrolides,” Medical Microbiology, 3rd Edition, Mosby Ltd, London, 2004, p. 489.

[9] A. Trevor, B. G. Katzung and S. Masters, "Chemotherapeutic Drugs: Chloramphenicol, Tetracyclines, Macrolides, Clindamycin, \& Streptogramins,” Pharmacology, 9th Edition, McGraw-Hill Medical, New York, December 2003, pp. 758-759.

[10] B. M. Tashtoush, E. L. Jacobson and M. K. Jacobson, “A Rapid HPLC Method for Simultaneous Determination of Tretinoin and Isotretinoin in Dermatological Formulations,” Journal of Pharmaceutical and Biomedical Analysis, Vol. 43, No. 3, February 2007, pp. 859-864.

[11] N. Takeda and A. Yamamoto, "Simultaneous Determination of 13-Cis- and All-Trans-Retinoic Acids and Retinol in Human Serum by High-Performance Liquid Chromatography," Journal of Chromatography B, Vol. 657, No. 1, July 1994, 53-59.

[12] B. Disdier, H. Bun, J. Catalin and A. Durand, "Simultaneous Determination of All-Trans-, 13-Cis-, 9-Cis-Retinoic Acid and Their 4-Oxo-Metabolites in Plasma by High-Performance Liquid Chromatography," Journal of Chromatography B, Vol. 683, No. 2, August 1996, pp. 143-154.

[13] B. Liawruangrath and S. Liawruangrath, "High Performance Thin Layer Chromatographic Determination of Erythromycin in Pharmaceutical Preparations,” Chromatographia, Vol. 54, No. 5, September 2001, pp. 405-408.

[14] Y. Kato, T. Yokoyama, M. Shimokawa, K. Kudo, J. Kabe and K. Mohri, "Determination of Erythromycin in Human Plasma and Whole Blood by High-Performance Liquid Chromatography,” Journal of Liquid Chromatography, Vol. 16, No. 3, February 1993, pp. 661-680.

[15] K. Tsuji and M. P. Kane, "Improved High-Performance Liquid Chromatographic Assay of Erythromycin in Pharmaceutical Solid Dosage Forms,” Journal of Pharmaceutical Sciences, Vol. 71, No. 10, October 1982, pp. 11601164.

[16] P. Dehouck, E. Van Looy, E. Haghedooren, K. Deckers, Y. Vander Heyden, E. Adams, E. Roets and J. Hoogmartens, "Analysis of Erythromycin and Benzoylperoxide in Topical Gels by Liquid Chromatography,” Journal of Chromatography B, Vol. 794, No. 2, September 2003, pp. 293-302.

[17] C. Stubbs and I. Kanfer, "High-Performance Liquid Chromatography of Erythromycin Propionyl Ester and Erythromycin Base in Biological Fluids," Journal of Chromatography: Biomedical Applications, Vol. 427, 1988, pp. 93-101.

[18] J. Wardrop, D. Ficker, S. Franklin and R. J. Gorski, “Determination of Erythromycin and Related Substances in Enteric-Coated Tablet Formulations by Reversed-Phase Liquid Chromatography,” Journal of Pharmaceutical Sciences, Vol. 89, No. 9, July 2000, pp. 1097-1105.

[19] ICH Q2 (R1), "Validation of Analytical Procedures: Text and Methodology," International Conference on Harmonization, Complementary Guideline on Methodology, Geneva, November 2005. 